This is the accepted version of the following article: Widodo, W. and Salim, R. and Bloch, H. 2014. Agglomeration Economies and Productivity Growth in Manufacturing Industry: Empirical Evidence from Indonesia. The Economic Record. 90 (s1): pp. 41-58., which has been published in final form at http://doi.org/10.1111/1475-4932.12115 


\title{
Agglomeration Economies and Productivity Growth in Manufacturing Industry: Empirical Evidence from Indonesia*
}

\author{
Wahyu Widodo ${ }^{1}$, Ruhul Salim ${ }^{2}$ and Harry Bloch ${ }^{3}$
}

\begin{abstract}
This study examines the effect of agglomeration economies on productivity growth in Indonesian manufacturing industries during the first decade of this century. Productivity growth is measured at the firm level using the Färe-Primont productivity index. Each firm's productivity growth is then regressed against a set of firm and industry characteristics, including three measures of agglomeration representing the effects of specialisation, diversity and competition. The results show evidence of a positive specialisation effect and a negative diversity effect for aggregate manufacturing and sub-sectors. Further, there are mixed effects across industries suggesting that Porter's competition externalities stimulate firm productivity growth under some conditions but not others.
\end{abstract}

Key words: agglomeration economies, externalities, and productivity growth

JEL classification: L25; L60; R12

*Helpful comments from two anonymous referees and the co-editor of the special issue, Peter Robertson, are gratefully acknowledged, but the authors are responsible for any remaining errors or omissions.

\footnotetext{
${ }^{1}$ Faculty of Economics and Business, Diponegoro University, Indonesia.

${ }^{2}$ School of Economics and Finance, Curtin University, Australia.

${ }^{3}$ School of Economics and Finance, Curtin University, Australia.
} 


\section{Introduction}

The concentration of economic activities in certain regions has become a common phenomenon in both developed and developing countries. Some of the most popular examples are the high-tech industry in the Silicon Valley or the auto industry in Detroit. In a spatial perspective, this feature is often referred to as agglomeration. Agglomeration economies, or location-specific economies, are independent of a single firm, but accrue to all of the firms located in the same area. Agglomeration economies are understood to provide economic reasons for the clustering of economic activities as well as the tendency of the geographic concentration of firms to persist over time (Andersoon and Lööf 2011).

The notion that agglomeration economies encourage spatial concentration has led to a good deal of research on the relation between agglomeration and productivity. The focus has been on whether agglomeration economies promote productivity growth. Glaeser et al. (1992) pioneered studies in this field, formulating the terminology "dynamic externalities" to explain how firms gain from external economies. The three types of dynamic externalities proposed by Glaeser et al. (1992) are Marshall-Arrow-Romer (MAR) externalities, Jacobs' externalities, and Porter's externalities, which are also referred to as specialisation, diversity, and competition, respectively. The core of the distinction among these concepts lies in the question of whether knowledge spillovers come from within the industry or from other industries, and the role of competition in influencing knowledge spillovers.

The MAR theory of spillovers deals with spillovers within an industry. Firms benefit from location and physical proximity through inter-firm exchanges of knowledge and information, reduced costs from labour pooling, and input sharing. The accumulated knowledge and experience of one firm is transmitted to other firms without appropriate compensation (Glaeser et al. 1992).

In contrast, Jacobs' (1969) theory of spillovers emphasises the role of diversity or variety in industries for promoting productivity growth. In a diversified area, the interchange of ideas and knowledge between firms is more frequent, so the variety of industries within a region stimulates knowledge externalities, which in turn results in local industrial productivity growth. Accordingly, regions with a diversified economic structure should perform better than specialised areas (Quigley 1998).

Finally, in terms of competition, Jacobs (1969) and Porter (1990) agree that local competition is more conducive to productivity growth, in contrast with MAR, who believe that local monopolies are more appropriate. Porter's model emphasises the idea that local competition forces firms to improve their ideas and to accelerate the imitation process. A high level of competition provides incentives for firms to innovate through higher allocations of R\&D spending (Combes 2000). The pressure to produce creative innovation is much greater in competitive regions, which then leads to improved technological progress, and hence productivity growth.

These insights about external economies have led empirical studies on agglomeration economies and productivity growth to focus on the disagreement between the two main theories of external economies, namely specialisation (or MAR externalities) and diversity (or Jacobs' externalities). However, the two theories are not necessarily mutually exclusive or always contradictory (Beaudry and Schiffauerova 2009). 
Our examination of the effect of agglomeration economies on productivity growth in Indonesian manufacturing industry is organised in seven sections. Following the introduction, Section 2 discusses industrial development and agglomeration in Indonesia. Section 3 provides the literature review. The analytical framework is discussed in Section 4, followed by discussion of the data and measurement of variables in Section 5. Section 6 contains the empirical analysis, and Section 7 presents conclusions.

\section{Industrial Development and Agglomeration in Indonesia}

Similar to many developing countries, Indonesia has adopted a strategy of rapid industrialisation by promoting the industries that use relatively simple technology and are labour intensive, such as textiles and garments (Felipe and Estrada 2007), or that are resources based, such as food and beverages. Since 1967, the Government of Indonesia has implemented six industrialisation stages (Ministry of Industry Republic of Indonesia 2009), with different targets, achievements, policies and challenges.

\section{Figure 1: Share of Manufacturing Industry to Gross Domestic Product (GDP), 1967-2009 (\%)}

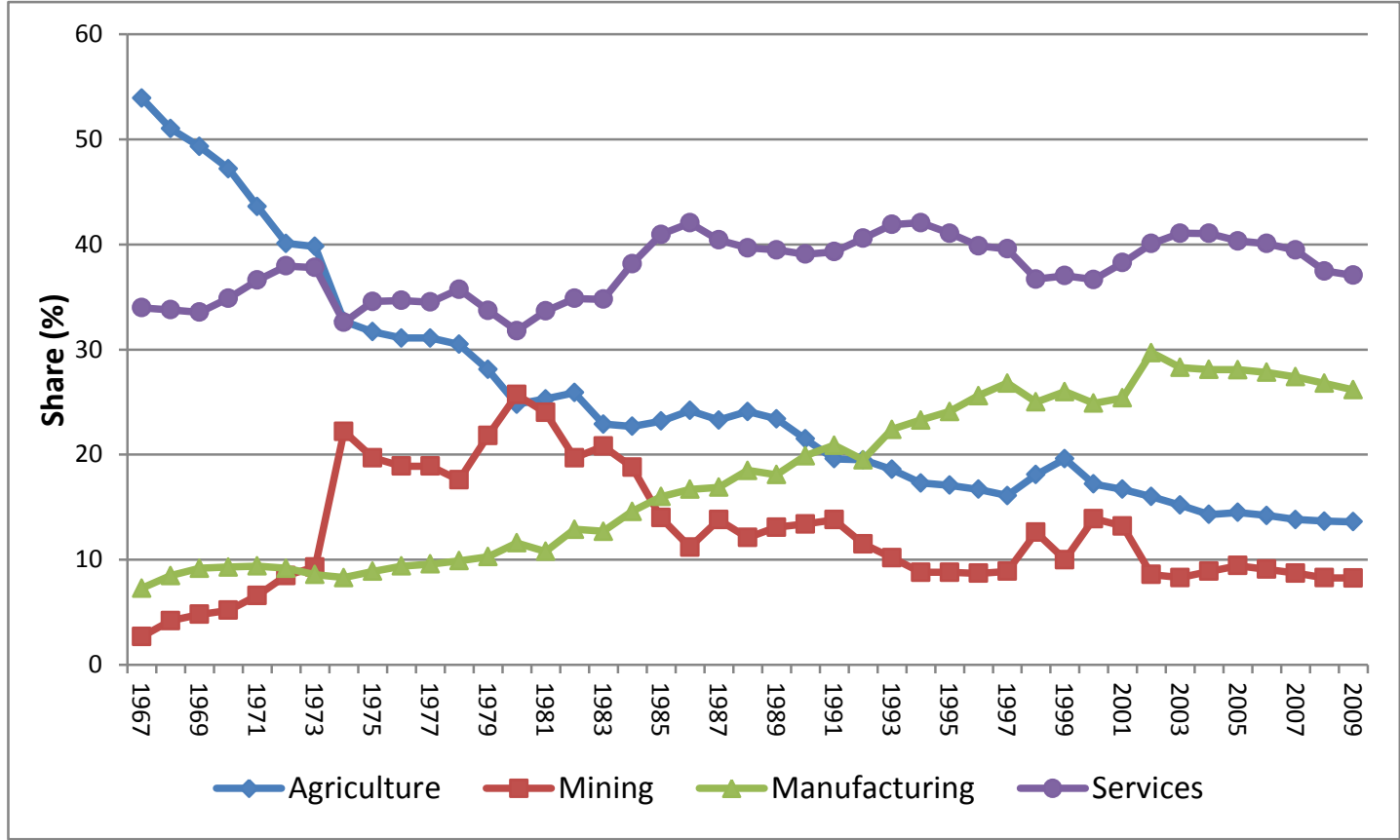

Source: Gross Domestic Product by Industrial Origin, Statistics Indonesia (Badan Pusat Statistik$B P S)$, various publications, author's calculation.

Note: The services sector consists of the government and private services; finance, real estate and business services; transport and communication; and trade, hotel and restaurants.

In a relatively short period, since the mid-1960s to just before the economic crisis in 1997, Indonesia has transformed from a stagnant economy dominated by the agrarian sector to one dominated by a strong manufacturing industry with its exports 
driving sustained economic growth (Jacob 2005). The structural transformation in Indonesia from 1967 to 2009 is illustrated in Figure 1. The manufacturing share of GDP increased substantially from only 7.3 percent in 1967 to 26.2 percent in 2009.

Table 1 describes the share of manufacturing value-added by industry subsectors over the stages of industrial development. Several interesting features are noticeable during the industrialisation periods. Firstly, since industrial development commenced in the early 1970s, two manufacturing industries have consistently sustained their share, namely the food and beverages industry (ISIC 15) and the chemical industry (ISIC 24), with an average share of value added in the period from 1976-2009 of $13.80 \%$ and $10.86 \%$, respectively.

Table 1: Industrialisation Stages and Average Share of Value Added in Manufacturing Industries 1976-2009, (\% of total, excluding oil and gas)

\begin{tabular}{|c|c|c|c|c|c|c|c|}
\hline \multirow{3}{*}{$\mathrm{KBLI}^{\mathrm{a})}$} & \multirow{3}{*}{ Industries } & \multicolumn{5}{|c|}{ Periods and Strategy } & \multirow{3}{*}{$\begin{array}{l}\text { Average } \\
\text { Share } \\
1976-2009\end{array}$} \\
\hline & & $\begin{array}{c}\text { Oil Boom } \\
(1976-1981)\end{array}$ & $\begin{array}{c}\text { Oil Price } \\
\text { Decline (1982- } \\
1985)\end{array}$ & $\begin{array}{c}\text { Oil Price } \\
\text { Decline (1986- } \\
1996)\end{array}$ & $\begin{array}{c}\text { Economic Crisis } \\
\text { and Recovery } \\
(1997-2004)\end{array}$ & $\begin{array}{l}\text { Recovery and } \\
\text { Development } \\
(2005-2009)\end{array}$ & \\
\hline & & $\begin{array}{c}\text { Inward } \\
\text { Looking (IL) }\end{array}$ & High Tech \& IL & $\begin{array}{l}\text { High Tech \& } \\
\text { Outward } \\
\text { Looking }(\mathrm{OL})\end{array}$ & $\begin{array}{l}\text { Revitalisation, IL } \\
\text { and OL }\end{array}$ & $\begin{array}{l}\text { Cluster, Regional } \\
\text { Approach, IL and } \\
\text { OL }\end{array}$ & \\
\hline 15 & Food and Beverages & 15.93 & 13.18 & 12.39 & 12.90 & 16.31 & 13.80 \\
\hline 16 & Tobacco & 24.32 & 21.67 & 12.22 & 10.90 & 9.04 & 14.69 \\
\hline 17 & Textile & 11.43 & 9.79 & 11.26 & 8.88 & 6.08 & 9.79 \\
\hline 18 & Garments & 0.72 & 1.45 & 3.26 & 3.80 & 3.43 & 2.75 \\
\hline 19 & Leather products & 0.94 & 0.78 & 2.20 & 2.76 & 1.80 & 1.88 \\
\hline 20 & Wood products & 4.53 & 7.21 & 9.62 & 6.04 & 2.90 & 6.61 \\
\hline 21 & Paper products & 1.20 & 1.12 & 2.97 & 5.48 & 5.75 & 3.44 \\
\hline 22 & $\begin{array}{l}\text { Printing, publishing and re- } \\
\text { production }\end{array}$ & 1.11 & 1.20 & 1.44 & 1.41 & 1.14 & 1.30 \\
\hline 24 & Chemical and chemical products & 11.33 & 11.20 & 9.32 & 10.55 & 13.93 & 10.86 \\
\hline 25 & Rubber products and plastics & 4.70 & 4.88 & 4.76 & 4.33 & 5.71 & 4.80 \\
\hline 26 & Non-metallic minerals & 6.53 & 5.12 & 3.67 & 3.91 & 4.01 & 4.45 \\
\hline 27 & Basic metal & 2.83 & 7.02 & 8.19 & 4.26 & 3.95 & 5.56 \\
\hline 28 & Metal products and equipment & 2.59 & 3.24 & 3.93 & 2.53 & 2.71 & 3.10 \\
\hline 29 & Machinery & 1.44 & 1.43 & 1.21 & 1.91 & 1.82 & 1.53 \\
\hline $30 / 33$ & Professionals equipment & 0.07 & 0.04 & 0.13 & 0.32 & 0.34 & 0.18 \\
\hline $31 / 32$ & Electrical equipment & 3.66 & 3.97 & 3.79 & 7.10 & 5.46 & 4.81 \\
\hline $34 / 35$ & $\begin{array}{l}\text { Motor vehicles and transport } \\
\text { equipment }\end{array}$ & 5.63 & 6.00 & 7.91 & 10.37 & 13.40 & 8.67 \\
\hline $36 / 37$ & Furniture and others & 0.41 & 0.43 & 1.41 & 2.47 & 2.22 & 1.49 \\
\hline
\end{tabular}

Source: Large and Medium Industrial Statistics 1976-2009, Statistics Indonesia (Badan Pusat Statistik $-B P S)$, author's calculation.

Note: ${ }^{\text {a) }}$ Based on the ISIC 1990 and Indonesian Standard Industrial Classification (Klasifikasi Baku Lapangan Usaha Indonesia - KBLI) 1997.

Two industries that dominated in the early stage of industrialisation, but whose contribution has steadily declined are the tobacco industry (ISIC 16) and textile industry (ISIC 17). In contrast, the motor vehicles and transport equipment 
industries (ISIC 34 and 35) show the most growth, with a combined share that increased from only $5.63 \%$ from 1976-1981 to $13.40 \%$ from 2005-2009. Similarly for the paper products industry (ISIC 21), the contribution increased from 1.2 percent in 1976-1981 to 5.79 percent in 2005-2009.

The success of the structural transformation at the national level has been matched by substantial progress in regional and spatial industrial development. Manufacturing industry tends to be concentrated in particular regions, such as around Jakarta (the capital of Indonesia) and other major provincial capitals, for example, Surabaya, Bandung, Semarang, Palembang, Medan and Batam. The concentration of industry around major provincial capitals is a natural process, because those cities serve as the centre of economic growth, with access to markets, economic resources, and bureaucracy.

Geographically, Indonesia is an archipelagic country with around 13,000 islands. It is one of the most spatially diverse nations in terms of its natural resources, population, and the location of its economic activities (Hill et al. 2008). In 2009, Indonesia consisted of 34 provinces and approximately 497 districts (kabupaten) and cities (kota). Table 2 describes the regional concentration of manufacturing based on provincial-level data from 1976-2009. Provinces are classified into five major groups of islands, as in Hill (1990).

As can be seen, manufacturing production and activities are mostly concentrated in Java, although its share of value added of decreased from 86.2 percent in the early stages of industrial development to 76.62 percent by 2009 . West Java, DKI Jakarta, East Java, and Banten dominated the distribution of manufacturing value added in Java, while the contribution of Central Java tended to decrease consistently. Sumatera is the second largest island for manufacturing production activity, with the major contributors being North Sumatera, Riau, South Sumatera, and Riau Islands. In Kalimantan, the manufacturing industries tend to concentrate in West Kalimantan and East Kalimantan, which are the two most developed provinces in this island. In Sulawesi, the concentration of industry is in South Sulawesi and North Sulawesi. 
Table 2: Geographical Concentration of Manufacturing Industry by Provinces 1976-2009 (\% of total value-added)

\begin{tabular}{lccrrrr}
\hline & $\mathbf{1 9 7 6}$ & $\mathbf{1 9 8 5}$ & $\mathbf{1 9 9 5}$ & $\mathbf{2 0 0 5}$ & $\mathbf{2 0 0 7}$ & $\mathbf{2 0 0 9}$ \\
\hline Aceh & 0.07 & 1.63 & 0.83 & 0.30 & 0.37 & 0.38 \\
North Sumatera & 3.78 & 5.14 & 4.41 & 3.35 & 4.42 & 3.52 \\
West Sumatera & 0.66 & 0.53 & 0.62 & 0.70 & 0.89 & 0.87 \\
Riau & 0.23 & 1.81 & 3.40 & 4.64 & 3.91 & 4.24 \\
Jambi & 0.12 & 0.66 & 0.59 & 1.38 & 1.12 & 0.55 \\
South Sumatera & 5.59 & 2.20 & 1.64 & 1.99 & 2.70 & 3.32 \\
Bengkulu & 0.00 & 0.11 & 0.03 & 0.04 & 0.06 & 0.11 \\
Lampung & 0.18 & 1.39 & 0.76 & 1.46 & 1.38 & 1.16 \\
Bangka Belitung & - & - & - & 0.19 & 0.73 & 0.56 \\
Riau Islands & - & - & - & 2.92 & 2.82 & 2.97 \\
\hline Sumatera & $\mathbf{1 0 . 6 5}$ & $\mathbf{1 3 . 4 7}$ & $\mathbf{1 2 . 2 8}$ & $\mathbf{1 6 . 9 6}$ & $\mathbf{1 8 . 4 0}$ & $\mathbf{1 7 . 6 9}$ \\
\hline Jakarta & 25.72 & 17.88 & 17.91 & 18.07 & 16.52 & 13.93 \\
West Java & 19.89 & 25.34 & 33.78 & 22.89 & 22.20 & 29.41 \\
Central Java & 14.53 & 10.29 & 6.47 & 5.49 & 6.68 & 5.93 \\
Yogyakarta & 1.36 & 0.39 & 0.43 & 0.46 & 0.28 & 0.25 \\
East Java & 24.73 & 22.42 & 23.52 & 20.28 & 20.08 & 17.18 \\
Banten & - & - & - & 9.62 & 10.15 & 9.93 \\
\hline Java & $\mathbf{8 6 . 2 4}$ & $\mathbf{7 6 . 3 2}$ & $\mathbf{8 2 . 1 2}$ & $\mathbf{7 6 . 8 1}$ & $\mathbf{7 5 . 9 1}$ & $\mathbf{7 6 . 6 2}$ \\
\hline West Kalimantan & 0.85 & 1.56 & 1.15 & 0.83 & 1.19 & 0.97 \\
Central Kalimantan & 0.35 & 0.68 & 0.38 & 0.24 & 0.41 & 0.69 \\
South Kalimantan & 0.34 & 1.66 & 0.99 & 0.77 & 0.60 & 0.89 \\
East Kalimantan & 0.23 & 2.78 & 1.47 & 2.35 & 1.30 & 1.18 \\
\hline Kalimantan & $\mathbf{1 . 7 6}$ & $\mathbf{6 . 6 8}$ & $\mathbf{4 . 0 0}$ & $\mathbf{4 . 2 0}$ & $\mathbf{3 . 5 1}$ & $\mathbf{3 . 7 4}$ \\
\hline North Sulawesi & 0.09 & 1.60 & 0.14 & 0.33 & 0.28 & 0.23 \\
Central Sulawesi & 0.02 & 0.09 & 0.04 & 0.05 & 0.07 & 0.04 \\
South Sulawesi & 0.80 & 0.72 & 0.51 & 0.86 & 0.95 & 0.77 \\
Southeast Sulawesi & 0.02 & 0.04 & 0.03 & 0.12 & 0.14 & 0.06 \\
Gorontalo & - & - & - & 0.02 & 0.07 & 0.08 \\
West Sulawesi & - & - & - & 0.01 & 0.06 & 0.07 \\
\hline Sulawesi & $\mathbf{0 . 9 4}$ & $\mathbf{2 . 4 5}$ & $\mathbf{0 . 7 2}$ & $\mathbf{1 . 3 9}$ & $\mathbf{1 . 5 7}$ & $\mathbf{1 . 2 5}$ \\
\hline Bali & 0.20 & 0.26 & 0.23 & 0.15 & 0.20 & 0.32 \\
West Nusa Tenggara & 0.07 & 0.07 & 0.03 & 0.02 & 0.02 & 0.07 \\
East Nusa Tenggara & 0.02 & 0.04 & 0.02 & 0.02 & 0.03 & 0.01 \\
Maluku & 0.10 & 0.35 & 0.27 & 0.16 & 0.14 & 0.14 \\
North Maluku & - & - & - & 0.16 & 0.00 & 0.00 \\
West Papua & 0.02 & 0.36 & 0.32 & 0.02 & 0.08 & 0.05 \\
Papua & - & - & - & 0.10 & 0.14 & 0.10 \\
\hline Eastern Indonesia & $\mathbf{0 . 4 1}$ & $\mathbf{1 . 0 8}$ & $\mathbf{0 . 8 9}$ & $\mathbf{0 . 6 4}$ & $\mathbf{0 . 6 1}$ & $\mathbf{0 . 7 0}$ \\
\hline Not Tab & & & & & \\
\hline
\end{tabular}

Note: Table format is adopted from Hill (1990)

Source: Large and Medium Industrial Statistics 1976-2009, Statistics Indonesia (Badan

Pusat Statistik-BPS), author's calculation.

\section{Literature Review}

The term "industrial district" was first introduced by Marshall (1920). Since then, the agglomeration model has received extensive attention from scholars (Maskell and 
Kebir 2006). ${ }^{1}$ In Marshall's model the agglomeration concept relates to the spatial concentration of economic activities. However, there is no standard definition of agglomeration in the literature. Wheeler et al. (1998) states that agglomeration refers to the geographic concentration of activities. According to Krugman (1991), industry agglomeration is formed from the existence of a demand linkage between firms, which is generated by the interaction of transportation costs with fixed costs of production. Accordingly, de Groot et al. (2009) explain that, historically, agglomeration of economic activities emerges due to the efficient and strategic advantages of settling at certain locations that have access to available resources (such as water and landscape) and the interrelated development of the trading path.

Marshall (1920) identifies three sources of agglomeration economies, input sharing, labour market pooling, and knowledge spillovers. Agglomeration is also triggered by the cost of transportation (Krugman 1991), the concentration of demand and natural advantage (Greenstone et al. 2008; Cohen and Paul 2009), local amenities (Greenstone et al. 2008), home market effects, and consumption and rent seeking (Rosenthal and Strange 2004).

Ohlin (1933) and Hoover (1937) expand Marshall's idea and propose a broader concept by distinguishing between localisation economies and urbanisation economies. Urbanisation economies refer to external economies in broader urban regions with more diversified economy. On the one hand, localisation economies can be viewed as external to the firm but internal to the industry in a specific region. They are also often associated with specialisation phenomena. On the other hand, the nature of urbanisation economies is that they are external to the firm, but internal to the whole region, such that they are able to provide benefits to all firms located in the region (Andersoon and Löö 2011). The concept of urbanisation economies is in line with the writings of Jacobs (1969), who describes the role of diversity in spatial economies.

Most early empirical studies consider the effect of agglomeration economies upon spatial growth using aggregate-level data. Among these studies are, for example, Glaeser et al. (1992), Henderson et al. (1995), Ellison and Glaeser (1997), Combes (2000), Duranton and Puga (2004), and Cingano and Schivardi (2004). Since productivity contributes importantly to economic growth and agglomeration is essentially a micro-behaviour, research in this field then shifted to examining the effect of agglomeration economies on firm productivity, using firm-level data rather than aggregated data. Henderson's (2003) seminal work is one of the first empirical studies of the effects of agglomeration economies on firm-level productivity growth.

Many studies similar to Henderson (2003) have been performed to examine the effect of agglomeration economies on productivity with different cases and regions. Positive effects of MAR externalities on productivity are found in Henderson et al. (2001), Henderson (2003), Duranton and Puga (2001), Lee et al. (2010), Kuncoro (2009), Graham and Kim (2008), and Anderson and Lööf (2011),

\footnotetext{
${ }^{1}$ Maskel and Kebir (2006) mention that in the period of 1953 to 2004 the number of articles published in scholarly journals within the social sciences with the term "cluster" and its synonyms as follows: cluster(s)/clustering of firm(s) (24); agglomeration (759); geographic(al) agglomeration(s) (11); spatial agglomeration(s) (43); agglomeration(s) of (same industry) firm(s) (126); geographic(al) concentration(s) (86); spatial concentration(s) (69); localised industries/firms (12); growth pole (26); innovative milieu(s) (34); industrial district(s) (231).
} 
while negative effects are found in Batisse (2002). Positive effects of Jacobs' externalities on productivity are mentioned in Henderson et al. (2001) and Capello (2002), while the negative effects are found in Frenken et al. (2005).

Meanwhile, empirical analysis of the relation between agglomeration economies and productivity growth in Indonesia has been very limited. Most previous studies use labour productivity as the main measure instead of using total factor productivity (TFP) growth. The use of TFP growth allows us to glean broader insights about the effects of agglomeration economies on productivity. Previous studies are also limited to a selection of sub-sector industries, which are not compared with the aggregate manufacturing industry. This leads to a loss of important information on the nature of agglomeration economies in the aggregate and in each sub-sector industry. This study attempts to enrich the research on agglomeration economies and productivity growth in the case of Indonesia by carrying out a level of analysis that has not been conducted previously.

\section{Analytical Framework}

Previous empirical research on agglomeration economies and firm productivity often employs the production function in which the agglomeration economies variables, firm inputs of production and other control variables are directly integrated in the model with one-stage estimation. Henderson (2003), for example, applies the production function based on a first-order Taylor series expansion of a general production function for a plant in a particular sub-industry, region and time. The dependent variable used in this model is labour productivity (Y/L). This approach is also followed by later studies, such as Kuncoro (2009) and Lee et al. (2010).

Rather than apply a one-stage approach, as in Henderson (2003) and other studies, this study uses a two-stage approach to estimate the impact of agglomeration economies on total factor productivity (TFP) growth. In the first stage, TFP growth is measured at the firm level using the Färe-Primont productivity index. In the second stage, each firm's productivity growth is then regressed against a set of firm and industry characteristics, including three measures of agglomeration representing the effects of specialisation, diversity and competition.

A disadvantage of the one-stage estimation method is that restrictions must be imposed on the functional form of the production function. While Henderson (2003) uses a first-order approximation to a general production function, second-order approximations, such as the translog production function, are more flexible. However, more parameters are required to be estimated and the parameters of the second-order terms are often only weakly significant and sometimes violate curvature restrictions.

The two-stage method to estimating the determinants of firm-level productivity avoids the need to specify the functional form of the production function as part of the estimation process. However, strong assumptions are made in calculating measures of productivity growth. For measures of total factor productivity growth, revenue per unit of output and expenditure per unit of input are used as weights in calculating aggregate measures of outputs and inputs. As Katayama, et al (2009) argue, this introduces systematic biases into measurement when prices deviate from average cost due to imperfect competition and economies of scale. The Färe-Primont index is utilised in this study as it provides a non- 
parametric measure of productivity that does not require strong assumptions about existence of competitive equilibrium. ${ }^{2}$ Construction of the Färe-Primont productivity index is detailed in the Appendix.

The empirical model for estimating the effect of agglomeration economies on productivity growth for a firm in a specific sub-industry and region at particular time is specified as:

$\mathrm{TFPGr}_{\mathrm{eij}(\mathrm{t})}=\alpha_{0}+\mathrm{AGG}_{\mathrm{j}(\mathrm{t})}^{\prime} \beta_{1}+\mathrm{Z}_{\mathrm{ei}(\mathrm{t})}^{\prime} \beta_{2}+\mathrm{D}_{\mathrm{j}}^{\prime} \beta_{3}+\varepsilon_{\mathrm{eij}(\mathrm{t})}$

where $\mathrm{TFPGr}_{\text {eij(t) }}$ is the measure of productivity growth for firm $e$ in industry $i$ and region $j$ at time $t$. $\mathrm{AGG}_{\mathrm{jt}}^{\prime}$ are agglomeration economies variables of region $j$ at time $t$, such that AGG consists of LQ (MAR externalities or specialisation), DIV (Jacobs externalities or diversity), and COM (Porter externalities or competition). ${ }^{3} \mathrm{Z}_{\text {eit }}^{\prime}$ are firm and industry characteristics that include firm age (AGE), firm size (SIZE), industry concentration (CR4), and industry-level entry of firms (ENT) and industrylevel exit of firms (EXT), while $\mathrm{D}_{\mathrm{j}}^{\prime}$ is a dummy variable representing urban area (DURB). The parameters to be estimated are $\beta_{1}, \beta_{2}$, and $\beta_{3}$. Finally, $\varepsilon_{\text {eij(t) }}$ represents the error term.

If there are unobservable fixed effects of industry and time period that affect TFP growth, the error term structure in the above model is:

$\varepsilon_{\mathrm{eij}(\mathrm{t})}=\delta_{\mathrm{i}}+\gamma_{\mathrm{t}}+\mu_{\mathrm{eij}(\mathrm{t})}$

where $\delta_{\mathrm{i}}$ and $\gamma_{\mathrm{t}}$ represents industry and time fixed effects, respectively. Without controlling for fixed effects, the estimation of agglomeration variables in Equation (1) is liable to bias whenever the fixed effects in Equation (2) are correlated with the observed variable.

The empirical model in Equation (1) is estimated using a panel data framework. Henderson (2003) is the first researcher to apply this method using firmlevel data in order to estimate the effect of Marshall's externalities on productivity growth. He argues that panel data allow deal with some of the selectivity issues that occur in cross-section models, and may help in dealing with endogeneity problems.

To estimate the model in Equation (1), the pooled ordinary least square (pooled-OLS) model is used, followed by the fixed effects within-group model (FEM within), random effects model (REM) and fixed effects least-squares dummy variable model (FEM LSDV). To determine whether the fixed effects model (FEM) or the random effects model (REM) is appropriate given the panel dataset available, a Hausman test is performed (Gujarati and Porter 2009).

\section{Data and Measurement Variables}

The data used in this study are provided by the Statistics Indonesia (Badan Pusat Statistik-BPS). Definitions of all variables used in the estimation are given in Table

\footnotetext{
${ }^{2}$ In comparison the standard accounting measure of TFP growth requires the assumption of perfectly competitive equilibrium or equivalent conditions that relate factor prices to marginal products.

${ }^{3}$ The detailed measurement method for the agglomeration economies is presented in the Appendix.
} 
3, while summary statistics are given in Table 4. Total factor productivity (TFP) growth is measured at the firm level using the Färe-Primont productivity index proposed by O'Donnell $(2010,2012)$. The variables representing agglomeration economies, i.e. LQ (specialisation), DIV (diversity) and COM (competition) are measured in two-digit ISIC and at the province level, which covers 22 industries and 33 provinces. Meanwhile, the dummy variable for urban and non-urban location is measured at the municipality/district level.

Table 3: Definition of Variables in the Model

\begin{tabular}{ll}
\hline \multicolumn{1}{c}{ Variables } & \multicolumn{1}{c}{ Definition } \\
\hline TFP growth & $\begin{array}{l}\text { Total factor productivity growth in percentage } \\
\text { LQ (specialisation) }\end{array}$ \\
DIV (diversity) & $\begin{array}{l}\text { Specialisation index, measured by Location Quotient (LQ) } \\
\text { Diversity index, measured by the inverse of the Hirschman- } \\
\text { Herfindahl Index (HHI) for the shares of each industry in a region. } \\
\text { Competition index, measured by the ratio of the specialisation } \\
\text { index (LQ) in terms of number of firms and LQ in terms of } \\
\text { number of employees. }\end{array}$ \\
AGE (firm age) & $\begin{array}{l}\text { Firm age, measured by number of years from the firm's } \\
\text { establishment to this survey. }\end{array}$ \\
SIZE (firm size) & $\begin{array}{l}\text { Firm size, measured by the natural logarithm of the number of } \\
\text { workers including production and non-production. }\end{array}$ \\
CR4 (concentration) & $\begin{array}{l}\text { Industrial concentration, measured by value added share in } \\
\text { percentage of the four largest firms in 2-digit ISIC level industry. }\end{array}$ \\
EXT (exit) & $\begin{array}{l}\text { Firm exit level, is percentage of the firms that exit from the } \\
\text { industry to the total of firms in each 2-digit ISIC }\end{array}$ \\
ENT (entry) & $\begin{array}{l}\text { Firm entry level, is percentage of the firms that enter to the } \\
\text { industry to the total of firms in each 2-digit ISIC } \\
\text { Dummy variable with value equal one to represent urban regions } \\
\text { and zero otherwise. }\end{array}$ \\
DURB (dummy) &
\end{tabular}

Table 4: Summary Statistics of the Variables

\begin{tabular}{lrrrr}
\hline \multicolumn{1}{c}{ Variable } & \multicolumn{1}{c}{ Mean } & \multicolumn{1}{c}{ SD } & \multicolumn{1}{c}{ Min } & \multicolumn{1}{c}{ Max } \\
\hline TFP growth & 15.85 & 52.90 & -83.76 & 679.73 \\
LQ (specialisation) & 0.96 & 0.22 & 0.28 & 2.47 \\
DIV (diversity) & 7.81 & 1.96 & 1.11 & 10.47 \\
COM (competition) & 0.99 & 0.13 & 0.44 & 3.10 \\
AGE (firm age) & 20.80 & 12.53 & 1.00 & 109.00 \\
SIZE (firm size) & 4.39 & 1.14 & 3.00 & 7.74 \\
CR4 (concentration) & 25.87 & 16.44 & 7.98 & 93.49 \\
EXT (exit) & 8.96 & 4.48 & 0 & 60.53 \\
ENT (entry) & 9.34 & 11.16 & 0 & 58.39 \\
DURB (dummy) & 0.52 & 0.50 & 0.00 & 1.00 \\
\hline
\end{tabular}


The estimation of Equation (1) is performed for the period from 2001 to 2009. Since a large number of capital values are missing, specifically within the period from 2001 to 2003, this study applies a back-casting method to estimate the missing values of capital to obtain a sufficient number of observations. This method has been used in previous studies, such as Vial (2006), Ikhsan (2007), and Suyanto et al. (2009). The final balanced panel dataset has data on 4,516 firms for each of the nine years and total observations are $40,644 .^{4}$

Figure 1 shows the average productivity growth by sub-sector industries from 2001 to 2009. Across all firms, the average TFP growth from 2001 to 2009 is 15.84 percent. The highest industry average is in radio, television and telecommunications (ISIC 32) with growth of 19.53 percent, while the lowest industry average is in both other non-metallic mineral products (ISIC 26) and recycling (ISIC 37) with growth of 14.17 percent.

Figure 1: Average TFP Growth by Industry 2001-2009 (\%)

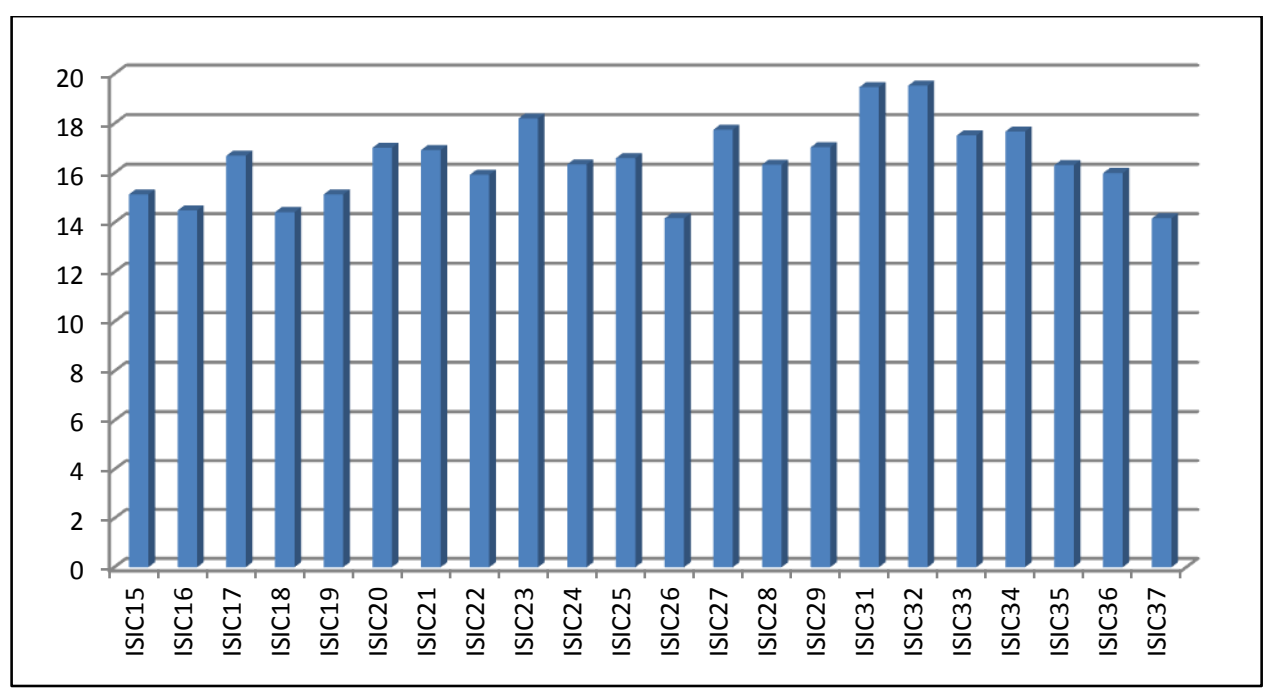

\section{Empirical Analysis}

\subsection{Estimation Approach}

Table 5 presents the estimation results of four different models. The first model (1) is the pooled OLS or population-average model with common effects. The second model (2) employs an assumption of random-effect using the generalized least squares (GLS) (REM). The third model (3) is the fixed-effect within transformation model (FEM within), while the fourth (4) uses fixed-effect least squares dummy variables model (FEM-LSDV).

The LSDV model allows for heterogeneity among cross-sectional units by allowing each unit or entity to have its own intercept value. The difference may be due to the special feature of firm or industry, such as managerial style, type of

\footnotetext{
${ }^{4}$ The procedures used for cleaning the data and creating a balanced panel of firms are available from the authors on request.
} 
market, or the structure of the industry. Model (4) also includes the time fixed effect, in which the F-test of this parameter shows that $\mathrm{F}(8,4515)=271.65$ with Prob $(F)=0.000$, strongly indicates that time fixed effect should be included in the model. Similar results are obtained for parameter test of industry fixed effects, in which $F(21,40605)=9.69$ with Prob $(F)=0.000$. Thus, Model (4) should have more reliable estimation results than other models. 5

Table 5: The Effect of Agglomeration Economies on TFP Growth 2001-2009

\begin{tabular}{|c|c|c|c|c|}
\hline Independent variables & Pooled OLS & REM & $\begin{array}{c}\text { FEM } \\
\text { (within) }\end{array}$ & FEM-LSDV \\
\hline & (1) & (2) & (3) & (4) \\
\hline LQ (specialisation) & $\begin{array}{r}11.292 \\
(7.80)^{\text {a) }}\end{array}$ & $\begin{array}{r}11.292 \\
(8.08)^{\text {a) }}\end{array}$ & $\begin{array}{r}24.180 \\
(13.12)^{a)}\end{array}$ & $\begin{array}{r}9.730 \\
(7.00)^{\mathrm{a}}\end{array}$ \\
\hline DIV (diversity) & $\begin{array}{r}-1.865 \\
\left.(-13.41)^{a}\right)\end{array}$ & $\begin{array}{r}-1.865 \\
(-11.70)^{a}\end{array}$ & $\begin{array}{r}-4.653 \\
(-16.56)^{\text {a) }}\end{array}$ & $\begin{array}{r}-1.067 \\
(-7.76)^{a}\end{array}$ \\
\hline $\mathrm{COM}$ (competition) & $\begin{array}{r}-1.066 \\
(-0.50)\end{array}$ & $\begin{array}{r}-1.066 \\
(-0.48)\end{array}$ & $\begin{array}{r}1.622 \\
(0.61)\end{array}$ & $\begin{array}{r}3.857 \\
(1.98)^{b}\end{array}$ \\
\hline AGE (firm's age) & $\begin{array}{r}-0.157 \\
(-7.86)^{a)}\end{array}$ & $\begin{array}{r}-0.157 \\
(-7.31)^{\text {a) }}\end{array}$ & $\begin{array}{r}-0.279 \\
(-5.58)^{a)}\end{array}$ & $\begin{array}{r}-0.069 \\
(-3.41)^{a}\end{array}$ \\
\hline SIZE (firm's size) & $\begin{array}{r}19.231 \\
\left.(-59.44)^{a}\right)\end{array}$ & $\begin{array}{r}19.231 \\
(62.48)^{\text {a) }}\end{array}$ & $\begin{array}{r}32.687 \\
(74.12)^{a}\end{array}$ & $\begin{array}{r}20.140 \\
(63.59)^{\mathrm{a}}\end{array}$ \\
\hline CR4 (concentration) & $\begin{array}{r}-0.057 \\
(-3.92)^{a}\end{array}$ & $\begin{array}{r}-0.057 \\
(-4.16)^{\text {a) }}\end{array}$ & $\begin{array}{r}-0.533 \\
(-16.42)^{a)}\end{array}$ & $\begin{array}{r}-0.118 \\
(-3.46)^{a}\end{array}$ \\
\hline EXT (exit) & $\begin{array}{r}0.285 \\
(4.91)^{a)}\end{array}$ & $\begin{array}{r}0.285 \\
(4.71)^{\text {a) }}\end{array}$ & $\begin{array}{r}0.251 \\
(4.01)^{\mathrm{a})}\end{array}$ & $\begin{array}{r}0.051 \\
(0.45)\end{array}$ \\
\hline ENT (entry) & $\begin{array}{l}-0.019 \\
(-1.26)\end{array}$ & $\begin{array}{r}-0.019 \\
(-1.75)^{\mathrm{c}}\end{array}$ & $\begin{array}{r}-0.114 \\
(-9.84)^{a)}\end{array}$ & $\begin{array}{r}0.311 \\
(4.50)^{\mathrm{a}}\end{array}$ \\
\hline DURB (dummy urban) & $\begin{array}{r}7.464 \\
(14.64)^{a)}\end{array}$ & $\begin{array}{r}7.464 \\
(12.38)^{a)}\end{array}$ & $\begin{array}{r}20.351 \\
(19.75)^{\text {a) }}\end{array}$ & $\begin{array}{r}8.168 \\
(15.90)^{\mathrm{a}}\end{array}$ \\
\hline Constant & $\begin{array}{r}-65.342 \\
\left.(-22.28)^{a}\right) \\
\end{array}$ & $\begin{array}{r}-65.342 \\
(-20.70)^{a)} \\
\end{array}$ & $\begin{array}{r}-108.377 \\
(-25.60)^{a)} \\
\end{array}$ & $\begin{array}{r}-78.333 \\
(-27.44)^{\text {a }} \\
\end{array}$ \\
\hline Dummy industry (2-digit ISIC) & - & - & - & Yes \\
\hline Dummy time (2001-2009) & - & - & - & Yes \\
\hline $\mathrm{N}$ & 4,516 & 4,516 & 4,516 & 4,516 \\
\hline Observations & 40,644 & 40,644 & 40,644 & 40,644 \\
\hline $\mathrm{R}^{2}$ & 0.1932 & 0.1932 & 0.1858 & 0.2488 \\
\hline
\end{tabular}

Hausman test for FEM: Probability $\left(\chi^{2}\right)=0.000 \rightarrow$ FEM

\footnotetext{
${ }^{5}$ In addition to using FEM-LSDV, the estimation of Equation (1) is also performed using FEM (within) with Driscoll and Kraay (1998) standard errors and first order autoregression (AR1), where these approaches are commonly used to eliminate autocorrelation problems in panel data. The results using these methods are similar for key control variables and mostly match for the effects of agglomeration economies upon total factor productivity growth. The FEM-LSDV estimates control for omitted explanatory variables that are associated with particular industries or time periods and are preferred for this reason. Detailed results of the alternative estimations are available from the authors.
} 
Note: t-statistics are shown in the parenthesis; a), b), and c) denote 1\%, 5\% and $10 \%$ significance level, respectively. The estimation is performed with robust standard error to control for heteroskedasticity.

To choose the appropriate model, either fixed effects or random effects, the Hausman test is employed. The overall statistic, $\chi^{2}(7)$, has $\rho=0.000$. This leads to strong rejection of the null hypothesis that individual effects are random, meaning that only the fixed-effects model can provide consistent estimates. To overcome heteroskedasticity problems, the estimation of the standard error in the FEM model is adjusted by the cluster-robust inference method. ${ }^{6}$

An important issue related to the estimation of Equation 1 is the possibility of reverse causality between agglomeration economies and productivity growth, which could lead to biased estimation results. Reverse causality between agglomeration economies and productivity growth is examined using the Engle-Granger causality test following Graham et al. (2010). Each agglomeration economies variable, specialisation (LQ), diversity (DIV) and competition (COM), is tested separately with productivity growth. The number of optimal lags for each causality test is determined to be equal to three for using the Akaike Information Criteria (AIC).

The results of the causality tests show that the F-test score for each of the agglomeration economies variables (LQ, DIV and COM) $\rightarrow$ productivity growth (TFPGr) is greater than F-table, meaning the rejection of $\mathrm{H}_{0}$ that agglomeration economies don't cause productivity growth. Similarly, the F-test score for each productivity growth (TFPGr) $\rightarrow$ agglomeration economies (LQ, DIV and COM) is also greater than the critical value in the F-table, indicating the rejection of $\mathrm{H}_{0}$ that productivity growth does not cause agglomeration. Thus, the Engle-Granger causality test shows that there is bi-directional causality between agglomeration economies and productivity growth, which may lead to possible bias of estimation results. The estimated coefficient for each of the agglomeration variables in Table 5 is influenced by the dynamic interdependence between agglomeration and productivity growth, rather than being a solely a direct measure of the influence of agglomeration on productivity.

\subsection{Agglomeration Economies Variables}

Findings from Table 5 show a positive effect of specialisation (LQ) on productivity growth, while diversity (DIV) has a negative effect on productivity growth. ${ }^{7}$ These findings confirm the MAR theory of agglomeration, in which knowledge and

\footnotetext{
${ }^{6}$ The estimation of panel data models is usually based on the assumption of the idiosyncratic error $\varepsilon_{i t} \sim\left(0, \sigma_{\varepsilon}^{2}\right)$. In fact, this assumption is often not satisfied in application. In this case, many panel estimators still retain consistency, provided that $\varepsilon_{i t}$ are independent over $i$, but reported standard errors are incorrect. In a short panel (few $\mathrm{T}$ and large $\mathrm{N}$ ), cluster-robust standard errors can be obtained under the assumption that errors are independent across $\mathrm{N}$ and that $\mathrm{N} \rightarrow \infty$. Specifically, $E\left(\varepsilon_{i t} \varepsilon_{j s}\right)=0$ for $i \neq j, E\left(\varepsilon_{i t} \varepsilon_{j s}\right)$ is unrestricted, and $\varepsilon_{i t}$ may be heteroskedastic. The approach leads to a cluster-robust estimate of the variance-covariance matrix of the estimator (VCE) (Cameron and Trivedi 2010).

${ }^{7}$ A referee notes that the estimates of the agglomeration coefficients may be biased due to spatial leakages outside of the province in which the firm is located. A full spatial model would incorporate leakages across adjacent provinces. However, the island geography, difficult terrain and underdeveloped infrastructure in Indonesia make it problematic to identify adjacent provinces.
} 
information spillovers among firms, as well as intra-industry backward-forward linkages, are effectively exchanged and transmitted in the regions that contain firms concentrated in the same industry. The results provide further support for positive effects of MAR externalities on productivity that are found in Henderson et al. (2001), Henderson (2003), Duranton and Puga (2001), Lee et al. (2010), Kuncoro (2009), Graham and Kim (2008), and Anderson and Lööf (2011).

The Jacobs theory of diversity encouraging productivity growth is rejected by our results. Previous studies have found mixed results, with positive effects of Jacobs' externalities on productivity mentioned in Henderson et al. (2001) and Capello (2002) and negative effects found in Frenken et al. (2005). Notably, Indonesian manufacturing is in the early stages of development, where internal and external economies of scale are likely to be particularly important and reflected in a positive effect of specialisation rather than diversity.

The third agglomeration economy variable is competition (or Porters' externalities). Its effect on productivity growth is positive and significant at the 5 percent level, implying that for the aggregated manufacturing industry, localised competition also significantly increases firm productivity growth. It confirms that a competitive industry in the province, with firms that are small relative to the national average, has higher firm productivity growth.

\subsection{Other Variables}

Moving to the effects of firm characteristics on productivity growth, Table 5 provides estimation results for firm age, size, industry concentration, firm exit and firm entry. Firm age (AGE) has a negative effect on productivity growth. Teece (1986) and Winter (1987) argue that younger firms have advantages in the area of knowledge, and the use of modern technology and sophisticated machinery. However, young firms often incur teething problems and longevity is evidence that performance has been good enough to survive. In Indonesia's case, our finding supports the studies of Pitt and Lee (1981), Hill and Kalirajan (1993), and Suyanto et al. (2009).

In addition, firm size (SIZE) has a positive effect on productivity growth. Large firms tend to have better market access and more professional management, and are faster in responding to changes in the business environment. This finding is similar to the findings of previous research such as Pitt and Lee's (1981) on the Indonesian weaving industry. Also, Bhandari and Ray (2012) find similar results for the Indian textile industry, Fan and Scott (2003) for furniture and plastic products in Chinese industries, Cingano and Schivardi (2004) for Italian manufacturing industries, and Kalkulis (2010) for the semi-conductor and pharmaceutical industries in the U.S.

The first variable representing industry characteristics is industrial concentration (CR4), which measures the share of the top four firms nationally in each industry sub-sector. The estimation results in Table 5 show that CR4 has a negative effect on productivity growth. This result further supports Porter's arguments about the positive effect of competition on firm performance and is in line with the findings of Setiawan et al. (2012). They find a negative relation between industrial concentration and the efficiency level in Indonesian food and beverage industries at the 5-digit ISIC level for the period from 1995 to 2006. 
The two other industry characteristics included in the model are the percentage of firm exists (EXT), which has a positive effect but is not significant, and the percentage of firm entries (ENT), which has a positive effect and is significant. Entry of firms may spur established firms to increase their own productivity, but entry may also reduce sales of established and lead to the loss of economies of scale. Exit of firms from an industry can increase economies of scale for remaining firms or lessen competitive pressure. The results in Table 5 indicate that the number of firms entering the industry stimulates TFP growth for continuing firms. Thus, high rates of entry suggest a dynamic industry environment that accelerates TFP growth.

Finally, the findings in Table 5 show positive effects of urban regions (DURB) on productivity growth, indicating that firms located in urban areas tend to have higher productivity relative to firms located outside urban areas. This result is expected, as urban areas are more developed than non-urban areas and serviced by better infrastructure.

\subsection{Analysis by Industry Sub-sector}

The estimation results by two-digit ISIC level are presented in Table $6 .{ }^{8}$ As with the results for aggregated industry, estimation at the two-digit industry level is also performed using fixed-effect least squares dummy variables (LSDV). Since each industry sub-sector has specific characteristics and a specific structure, it is possible to determine whether there are differing effects of agglomeration economies on productivity growth. Most empirical studies of agglomeration economies and productivity, such those of Henderson (2003), Kuncoro (2009), and Andersoon and Lööf (2011), are performed by selecting particular industries.

In general, the empirical findings for agglomeration by industry sub-sector in Table 6 are in accordance with the results for the aggregated industry in Table 5. Specialisation (or MAR externalities) has a significant positive effect on productivity growth for all two-digit manufacturing industries, except for chemicals and chemical products industry (ISIC 24) and fabricated metal products industry (ISIC 28), in which the effects are not significant and positive and negative, respectively. Diversity (or Jacobs' externalities) negatively affects almost all manufacturing sectors, except for positive and not statistically significant effects in the chemicals and chemical products industry (ISIC 24), rubber and plastic products industry (ISIC 25) and basic metal industry (ISIC 27).

Moving to the effect that competition (or Porter's externalities) exerts on productivity growth, the findings for two-digit industry sub-sectors in Table 6 are mixed. According to Glaeser et al. (1992), there are two different views on the effect of competition upon growth. In MAR model, local concentration is better than local competition because innovators internalise the externalities, while in Porter's model local competition is better because it accelerates imitations and improvement of innovator's ideas. From Table 6, a positive and statistically significant effect of competition on productivity growth is found in several manufacturing industries, including the tobacco industry (ISIC 16) and machinery and equipment (ISIC 29). These results are consistent with that for aggregated manufacturing and support

\footnotetext{
${ }^{8}$ Industries with fewer than twenty firms are omitted as their results may be viewed as unreliable.
} 
Porter's (1990) argument that competition stimulates firm productivity. However, a significant negative effect on productivity growth is found in textiles industry (ISIC 17), paper and paper products industry (ISIC 21), chemicals and chemical products industry (ISIC 24) and furniture industry (ISIC 36). These results are in accordance to the MAR model that local concentration favours firm productivity.

Firm size (SIZE) has a positive and statistically significant effect on productivity growth for all two-digit industry sub-sectors in Table 6, which confirms the results of the aggregate sample of industries in Table 5. However, the estimation results in Table 6 show that firm age (AGE) has a negative effect for only some of the industries at the two-digit level and this effect is statistically significant in only four industry sub-sectors i.e. publishing and printing industry (ISIC 22), chemical and chemical products industry (ISIC 24), basic metals industry (ISIC 27) and other transport equipment industry (ISIC 35). A positive and statistically significant effect of age on productivity growth occurs in the apparel industry (ISIC 18). Therefore, the findings at the two-digit industry level are only generally in line with the negative effect for aggregate manufacturing presented in Table 5 and the effect of age on productivity growth in a particular industry can be positive or negative, suggesting that the effect is sensitive to industry characteristics that we have not modelled directly.

The results for industry characteristic variables in Table 6 reflect only the impact of changes in these variables over time, while the results in Table 5 reflect also the much greater variation in industry characteristics across industries. Perhaps not surprisingly, a mixed pattern of results in terms of the direction and significance of these characteristics is found across industries. Industrial concentration CR4 has a negative and statistically significant effect on productivity growth in almost half of the two-digit industry sub-sectors, supporting the results for the aggregate sample in Table 5. Exceptional industries showing a positive and statistically impact of CR4 are ISIC 21, 24, 25 and 36.

The effect of firm entry (ENT) and exit (EXT) on productivity growth also vary across industries in Table 6. Firm exit (EXT) has a negative and significant effect on productivity growth in ISIC 15, 16, 21 and 36, but a positive and significant effect for ISIC 17, 18, 26 and 34. In contrast to the positive and significant result for the full sample in Table 5, firm entry (ENT) has a negative and significant effect on productivity growth in 7 out of 18 industries at the two-digit industry level together with a positive and significant effect only in ISIC 16. 
Table 6: The Effect of Agglomeration Economies and Firm Characteristics on TFP Growth at 2-Digit ISIC, 2001-2009

\begin{tabular}{|c|c|c|c|c|c|c|c|c|c|}
\hline Independent variables & ISIC 15 & ISIC 16 & ISIC 17 & ISIC 18 & ISIC 19 & ISIC 20 & ISIC 21 & ISIC 22 & ISIC 24 \\
\hline \multirow[t]{2}{*}{ LQ (specialisation) } & 9.09 & 23.23 & 32.80 & 28.44 & 47.56 & 14.61 & 46.54 & 14.35 & -0.77 \\
\hline & $(2.71)^{\mathrm{a})}$ & $(1.79)^{\mathrm{c})}$ & $(6.19)^{\mathrm{a})}$ & $(4.31)^{\mathrm{a})}$ & $(2.84)^{a)}$ & $(1.84)^{\mathrm{c})}$ & $(3.90)^{\mathrm{a})}$ & $(2.00)^{b)}$ & $(-0.11)$ \\
\hline \multirow[t]{2}{*}{ DIV (diversity) } & -0.48 & -7.70 & -6.65 & -3.80 & -1.93 & -1.39 & -3.34 & -5.44 & 0.29 \\
\hline & $(-0.89)$ & $(-4.21)^{a)}$ & $(-6.60)^{a)}$ & $(-2.67)^{a)}$ & $(-0.84)$ & $(-1.24)$ & $(-1.93)^{c)}$ & $(-4.22)^{a)}$ & $(0.27)$ \\
\hline \multirow[t]{2}{*}{ COM (competition) } & 3.63 & 126.95 & -17.63 & -0.37 & 6.47 & 2.87 & -20.84 & -13.81 & -24.66 \\
\hline & $(0.78)$ & $(4.71)^{\mathrm{a})}$ & $(-2.14)^{a)}$ & $(-0.03)$ & $(0.27)$ & $(0.29)$ & $(-1.45)$ & $(-1.06)$ & $(-2.23)^{b)}$ \\
\hline \multirow[t]{2}{*}{ AGE (firm's age) } & 0.07 & -0.20 & -0.02 & 0.68 & -0.04 & 0.32 & -0.33 & -0.43 & -0.38 \\
\hline & $(0.74)$ & $(-1.01)$ & $(-0.13)$ & $(2.76)^{a)}$ & $(-0.09)$ & $(1.20)$ & $(-1.14)$ & $\left.(-2.05)^{b}\right)$ & $(-1.88)^{\mathrm{c})}$ \\
\hline \multirow[t]{2}{*}{ SIZE (firm's size) } & 34.61 & 38.07 & 34.75 & 30.43 & 34.09 & 35.09 & 33.60 & 37.14 & 35.57 \\
\hline & $(39.78)^{a)}$ & $(16.51)^{a)}$ & $(27.34)^{a)}$ & $(19.10)^{a)}$ & $(9.10)^{a)}$ & $(18.20)^{a)}$ & $(14.33)^{\mathrm{a})}$ & $(14.64)^{a)}$ & $(18.97)^{a)}$ \\
\hline \multirow[t]{2}{*}{ CR4 (concentration) } & 0.34 & -8.54 & -0.43 & -0.65 & -0.02 & -0.35 & 2.58 & -0.25 & 0.13 \\
\hline & $(2.31)^{\mathrm{b})}$ & $(-5.75)^{a)}$ & $(-3.87)^{a)}$ & $\left.(-2.68)^{a}\right)$ & $(-0.05)$ & $(-0.54)$ & $(2.13)^{b)}$ & $(-0.36)$ & $(2.17)^{b)}$ \\
\hline \multirow[t]{2}{*}{ EXT (exit) } & -2.86 & -24.28 & 0.45 & 0.43 & 1.62 & 0.19 & -2.68 & 0.13 & -0.48 \\
\hline & $(-3.61)^{a)}$ & $(-4.73)^{a)}$ & $(2.11)^{b)}$ & $(2.30)^{\mathrm{b})}$ & $(1.56)$ & $(0.55)$ & $(-2.67)^{a)}$ & $(0.42)$ & $(-0.90)$ \\
\hline \multirow[t]{2}{*}{ ENT (entry) } & 1.46 & 13.11 & -5.39 & -5.78 & -4.48 & -2.51 & 8.86 & -2.66 & 0.20 \\
\hline & (1.36) & $(2.85)^{\mathrm{a})}$ & $\left.(-9.20)^{a}\right)$ & $\left.(-8.56)^{a}\right)$ & $(-2.16)^{b)}$ & $(-5.34)^{a)}$ & (1.47) & $(-1.32)$ & $(0.19)$ \\
\hline \multirow[t]{2}{*}{ Constant } & -165.86 & 507.16 & -87.71 & -124.33 & -207.71 & -136.74 & -262.48 & -105.57 & -89.65 \\
\hline & $(-12.20)^{a)}$ & $(3.85)^{\mathrm{a})}$ & $(-5.84)^{a)}$ & $(-5.60)^{a)}$ & $(-6.82)^{a)}$ & $(-6.51)^{a)}$ & $(-3.37)^{a)}$ & $(-4.18)^{a)}$ & $(-3.97)^{a)}$ \\
\hline Dummy time & Yes & Yes & Yes & Yes & Yes & Yes & Yes & Yes & Yes \\
\hline $\mathrm{N}$ & 1,148 & 151 & 476 & 213 & 88 & 212 & 105 & 117 & 273 \\
\hline Observations & 9,184 & 1,208 & 3,808 & 1,704 & 704 & 1,696 & 840 & 936 & 2,184 \\
\hline $\mathrm{R}^{2}$ & 0.3705 & 0.4341 & 0.3817 & 0.3550 & 0.3584 & 0.3803 & 0.4042 & 0.4461 & 0.4040 \\
\hline
\end{tabular}

Note: t-statistics are in the parenthesis; a), b), and c) denote $1 \%, 5 \%$ and $10 \%$ significance level, respectively. The estimation is performed with robust standard error to control for heteroskedasticity.

\footnotetext{
${ }^{12}$ Variable DURB (dummy for urban location) is omitted, because at 2-digit ISIC levels, several industries have firms located only at urban or non-urban locations Four industries with sample less than 20 firms are excluded, i.e. ISIC 23: Coal, petroleum, and nuclear; ISIC 32: Radio, television, and communication; ISIC 33: Medical, precision, and optical instruments; and ISIC 37: Recycling.
} 
Table 6: (continued...)

\begin{tabular}{|c|c|c|c|c|c|c|c|c|c|}
\hline Independent variables & ISIC 25 & ISIC 26 & ISIC 27 & ISIC 28 & ISIC 29 & ISIC 31 & ISIC 34 & ISIC 35 & ISIC 36 \\
\hline LQ (specialisation) & $\begin{array}{r}23.12 \\
(4.55)^{\text {a) }}\end{array}$ & $\begin{array}{r}41.53 \\
(7.15)^{\text {a) }}\end{array}$ & $\begin{array}{l}11.14 \\
(0.80)\end{array}$ & $\begin{array}{r}33.67 \\
(3.97)^{\text {a) }}\end{array}$ & $\begin{array}{r}44.32 \\
(3.38)^{\text {a) }}\end{array}$ & $\begin{array}{r}29.49 \\
(1.84)^{c)}\end{array}$ & $\begin{array}{r}24.06 \\
(2.17)^{\mathrm{b})}\end{array}$ & $\begin{array}{r}22.92 \\
(2.24)^{b)}\end{array}$ & $\begin{array}{r}26.83 \\
(4.59)^{a)}\end{array}$ \\
\hline DIV (diversity) & $\begin{array}{r}0.19 \\
(0.25)\end{array}$ & $\begin{array}{r}-2.86 \\
(-2.69)^{\text {a) }}\end{array}$ & $\begin{array}{r}0.92 \\
(0.36)\end{array}$ & $\begin{array}{r}-2.96 \\
(-2.37)^{b)}\end{array}$ & $\begin{array}{r}-4.71 \\
(-2.23)^{b)}\end{array}$ & $\begin{array}{r}-0.31 \\
(-0.13)\end{array}$ & $\begin{array}{r}-4.57 \\
(-2.19)^{b)}\end{array}$ & $\begin{array}{r}-1.17 \\
(-0.77)\end{array}$ & $\begin{array}{r}-1.13 \\
(-1.21)\end{array}$ \\
\hline COM (competition) & $\begin{array}{r}2.18 \\
(0.27)\end{array}$ & $\begin{array}{r}9.09 \\
(1.01)\end{array}$ & $\begin{array}{l}11.12 \\
(0.75)\end{array}$ & $\begin{array}{r}9.96 \\
(0.87)\end{array}$ & $\begin{array}{r}37.33 \\
(1.71)^{\mathrm{c})}\end{array}$ & $\begin{array}{l}21.12 \\
(0.76)\end{array}$ & $\begin{array}{r}24.64 \\
(1.15)\end{array}$ & $\begin{array}{r}-6.88 \\
(-0.70)\end{array}$ & $\begin{array}{r}-15.19 \\
(-1.79)^{c)}\end{array}$ \\
\hline AGE (firm's age) & $\begin{array}{r}-0.26 \\
(-1.57)\end{array}$ & $\begin{array}{r}0.26 \\
(1.55)\end{array}$ & $\begin{array}{r}-0.94 \\
(-2.04)^{b}\end{array}$ & $\begin{array}{r}0.10 \\
(0.40)\end{array}$ & $\begin{array}{r}-0.14 \\
(-0.57)\end{array}$ & $\begin{array}{r}0.40 \\
(0.87)\end{array}$ & $\begin{array}{r}0.54 \\
(1.31)\end{array}$ & $\begin{array}{r}-0.73 \\
(-1.87)^{c}\end{array}$ & $\begin{array}{r}0.33 \\
(1.16)\end{array}$ \\
\hline SIZE (firm's size) & $\begin{array}{r}33.42 \\
(27.09)^{\mathrm{a})}\end{array}$ & $\begin{array}{r}38.94 \\
(26.69)^{\text {a) }}\end{array}$ & $\begin{array}{r}30.38 \\
(8.76)^{a)}\end{array}$ & $\begin{array}{r}36.11 \\
(15.91)^{a)}\end{array}$ & $\begin{array}{r}35.25 \\
(11.60)^{a)}\end{array}$ & $\begin{array}{r}39.60 \\
(10.41)^{a)}\end{array}$ & $\begin{array}{r}32.66 \\
(11.94)^{a)}\end{array}$ & $\begin{array}{r}38.01 \\
(11.27)^{a)}\end{array}$ & $\begin{array}{r}37.32 \\
(22.36)^{\text {a) }}\end{array}$ \\
\hline CR4 (concentration) & $\begin{array}{r}1.73 \\
(1.55)\end{array}$ & $\begin{array}{r}1.86 \\
(3.12)^{\mathrm{a})}\end{array}$ & $\begin{array}{r}-0.23 \\
(-0.38)\end{array}$ & $\begin{array}{r}-0.25 \\
(-1.55)\end{array}$ & $\begin{array}{r}-0.22 \\
(-0.98)\end{array}$ & $\begin{array}{r}-1.37 \\
(-1.77)\end{array}$ & $\begin{array}{r}1.50 \\
(1.51)\end{array}$ & $\begin{array}{r}-0.02 \\
(-0.03)\end{array}$ & $\begin{array}{r}0.98 \\
(2.36)^{\text {a) }}\end{array}$ \\
\hline EXT (exit) & $\begin{array}{r}-1.19 \\
(-1.40)\end{array}$ & $\begin{array}{r}2.41 \\
(2.76)^{\text {a) }}\end{array}$ & $\begin{array}{r}-0.37 \\
(-0.69)\end{array}$ & $\begin{array}{r}-0.07 \\
(-0.15)\end{array}$ & $\begin{array}{r}0.19 \\
(0.18)\end{array}$ & $\begin{array}{r}0.76 \\
(0.46)\end{array}$ & $\begin{array}{r}2.89 \\
(1.81)^{\mathrm{c})}\end{array}$ & $\begin{array}{r}1.09 \\
(1.23)\end{array}$ & $\begin{array}{r}-2.99 \\
(-2.00)^{b)}\end{array}$ \\
\hline ENT (entry) & $\begin{array}{r}3.53 \\
(1.03)\end{array}$ & $\begin{array}{r}-8.38 \\
(-4.46)^{\text {a) }}\end{array}$ & $\begin{array}{r}2.17 \\
(0.91)\end{array}$ & $\begin{array}{r}-1.21 \\
(-1.42)\end{array}$ & $\begin{array}{r}-2.54 \\
(-1.56)\end{array}$ & $\begin{array}{r}-12.30 \\
(-2.29)^{b)}\end{array}$ & $\begin{array}{r}-10.24 \\
(-3.13)^{a)}\end{array}$ & $\begin{array}{r}-2.83 \\
(-1.50)\end{array}$ & $\begin{array}{r}7.49 \\
(1.55)\end{array}$ \\
\hline Constant & $\begin{array}{r}-216.22 \\
(-9.31)^{\text {a) }}\end{array}$ & $\begin{array}{r}-282.45 \\
(-9.31)^{\text {a) }} \\
\end{array}$ & $\begin{array}{r}-172.09 \\
(-4.10) \\
\end{array}$ & $\begin{array}{r}-179.31 \\
(-8.08)^{\mathrm{a})} \\
\end{array}$ & $\begin{array}{r}-170.91 \\
(-5.16)^{a)} \\
\end{array}$ & $\begin{array}{r}-158.23 \\
(-3.31) \\
\end{array}$ & $\begin{array}{r}-251.09 \\
(-3.53)^{\mathrm{a})} \\
\end{array}$ & $\begin{array}{r}-116.73 \\
(-2.87)^{a)} \\
\end{array}$ & $\begin{array}{r}-212.27 \\
(-8.76)^{a)}\end{array}$ \\
\hline Dummy time & Yes & Yes & Yes & Yes & Yes & Yes & Yes & Yes & Yes \\
\hline $\mathrm{N}$ & 429 & 389 & 54 & 182 & 84 & 60 & 70 & 67 & 243 \\
\hline Observations & 3432 & 3112 & 432 & 1,456 & 672 & 480 & 560 & 536 & 2,744 \\
\hline $\mathrm{R}^{2}$ & 0.3990 & 0.4718 & 0.4297 & 0.4014 & 0.4190 & 0.4816 & 0.4746 & 0.3932 & 0.3937 \\
\hline
\end{tabular}

Note: t-statistics are in the parenthesis; a), b), and c) denote $1 \%, 5 \%$ and $10 \%$ significance level, respectively. The estimation is performed with robust standard error to control for heteroskedasticity.

ISIC 15: Food products and beverages; ISIC 16: Tobacco; ISIC 17: Textiles; ISIC 18: Apparel; ISIC 19: Tanning and dressing of leather; ISIC 20: wood and wood products; ISIC 21: Paper and paper products; ISIC 22: Publishing and printing; ISIC 24: Chemicals and chemical products; ISIC 25: Rubber and plastics products ISIC 26: Other non-metallic mineral products; ISIC 27: Basic metals; ISIC 28: Fabricated metal products; ISIC 29: Machinery and equipment n.e.c; ISIC 31: Electrical machinery and apparatus n.e.c; ISIC 34: Motor vehicles; ISIC 35: Other transport equipment; ISIC 36: Furniture. 
The contrast in the effect of entry on productivity growth between the fullsample result and that for the industry sub-samples is an exception. Overall, the results for the two-digit industry sub-samples are generally consistent with the corresponding results for the full sample. Where the results are highly significant in the full sample, such as for the effects of LQ, DIV and SIZE, the corresponding coefficients in the two-digit sub-samples are of the same sign, with the odd exception, and generally statistically significant, Where the estimated coefficient has a lower t-ratio in the full sample, the pattern of signs and significance across the industry sub-samples is more mixed. With many of the variables there are arguments for either a positive or negative impact on productivity. More specific measures related to the conflicting arguments might be able to further clarify the influences, but such measures are not available for this study. Without being able to make finer distinctions, a mixed pattern of results for our measured variables across industries is not surprising.

\section{Conclusion}

Our empirical findings show evidence of a positive specialisation effect and negative diversity effect for Indonesian manufacturing, indicating that specialisation is favourable to the stimulation of productivity growth while diversity is unfavourable. These results are found to be robust to alternative estimation methods for aggregate manufacturing and to apply across separate regressions for each of 18 industry subsectors with only a few exceptions. Clearly, the geographic concentration of firms in a particular manufacturing activity increases productivity growth along the lines suggested by the Marshall-Arrow-Romer analysis of external economies. Also our findings for all firms show that firms located in urban areas have enjoyed faster productivity growth than those outside the urban areas, but we are not able to examine this phenomenon at the industry sub-sector level because many industries have too few firms located outside urban areas.

Our findings with respect to the effect of localised competition are less clearcut. Across the full sample of firms, local competition (or Porter's externalities) exerts a positive and weakly statistically significant effect on productivity growth. However, there are only two two-digit industries in which local competition exerts a positive and statistically significant influence on productivity growth, while there is a negative and statistically significant effect in three industries.

In terms of firm and industry characteristic effects on productivity growth, we find that firm size (SIZE) has a positive and statistically significant effect that is robust to alternative estimation methods for aggregate manufacturing and consistent across all 18 industry sub-sectors. The effect of both firm age (AGE) and industry concentration (CR4) are negative and statistically significant across all estimation methods for aggregate manufacturing, but the results for sub-sectors are mixed. The effects of entry and exit of firms are positive at the aggregate level, although only the entry variable is statistically significant. However, the effects are mixed for industry sub-sectors, with a preponderance of negative and statistically significant effects for entry.

The results of this study should be viewed in the context of the rapid growth of manufacturing activity in Indonesia over the sample period of the first decade of the current century. Large firms in industries operating in urban areas and in close geographical proximity to others in the same line of business have achieved 
particularly high rates of productivity growth. This suggests that internal and external economies have been important to learning and adoption of modern manufacturing technology that has enhanced productivity growth. Similar results have been found in other rapidly developing economies and provide important information to policy makers in these countries for guiding manufacturing development. Results for the impact of local competition, firm age and industry characteristics of concentration, entry and exit are more varied across industry sub-sectors, suggesting a need to consider policy in relation to the circumstances of the individual sub-sector. 


\section{APPENDIX}

\section{The Measurement of TFP Growth}

The measurement of TFP growth is performed using Färe-Primont productivity index developed by O'Donnell $(2010,2012)$. This is a relatively new index-based method for measuring productivity change. O'Donnell (2012) proposes a measurement approach which meets all the required axioms of productivity index measurement, so that the Färe-Primont productivity index of O'Donnell (2012) is categorised as a "multiplicatively-complete" productivity index. The Färe-Primont productivity index measurement proposed by O'Donnell $(2010,2012)$ is adapted from the estimation of Shepard (1953) output distance functions and associated measures of productivity change.

O'Donnell (2010, 2012) explains that if $x_{i t}=\left(x_{1 i t}, \ldots, x_{K i t}\right)$, and $q_{i t}=\left(q_{1 i t}, \ldots, q_{J i t}\right)$ ' denotes the vectors of input and output quantities for firm $i$ and period $t$. The TFP of a firm in the aggregate quantity framework of O'Donnell (2011, 2012) is defined as:

$$
\operatorname{TFP}_{i t}=\frac{Q_{i t}}{X_{i t}}
$$

where $Q_{i t} \equiv Q\left(q_{i t}\right)$ represents the aggregate output, and $X_{i t} \equiv X\left(x_{i t}\right)$ is the aggregate input, and $Q($.$) and X($.$) are non-negative, non-decreasing and linearly-homogenous$ aggregator functions.

In summary, the Färe-Primont index to measure and decompose the TFP growth can be written as (O'Donnell 2011a):

$T F P_{m s, n t}=\left(\frac{A(t)}{A(s)}\right)\left(\frac{g\left(q_{n t}\right)}{A(t) f\left(x_{n t}\right)} \frac{A(s) f\left(x_{m s}\right)}{g\left(q_{m s}\right)}\right)\left(\frac{f\left(x_{m s}\right)}{f\left(x_{n t}\right)}\right)^{(1-\eta) / \eta}$

where $T F P_{m s}$ denotes the TFP of firm $m$ in period $s$ and $T F P_{n t}$ is the TFP of firm $n$ in period $t$, the scale elasticity $(\eta)$ and technology (A). From Equation A2, the first component in the right hand side represents the technical change or technical progress, the second component is output technical efficiency change, and the third component is scale efficiency change. If there is no technical inefficiency and the technology exhibits constant return to scale (CRS), the index collapses to the "Solow residual" (O'Donnell 2012).

\section{The Measurement of Agglomeration Economies}

\section{Specialisation (MAR externalities)}

As explained in Nakamura and Paul (2009), regional specialisation is measured by location quotient (LQ), which is defined as the share of industry $i$ 's employment relative to total industry employment in a specific region $j$ in contrast with the share of region $j$ 's employment relative to total (national) employment in industry $i$. In this study, industry is represented by 2-digit ISIC, which included 22 sectors and region is measured at province level, which included 33 regions. The regional specialisation index relative to national industrial composition can be written as (Nakamura and Paul 2009):

$L Q_{i j}^{S}=\frac{s_{i j}^{S}}{s_{i^{*}}}=\frac{x_{i j} / x_{* j}}{x_{i *} / x_{* *}}, i=1, \ldots, I$. 
$L Q_{i j}^{S}$ represents the specialisation of industry $i$ in region $j$ relative to the specialisation of industry $i$ in aggregated regions. The average of the regional specialisation index across industries can be calculated by taking the average value of $L Q_{i j}^{S}$ :

$L O C_{j}^{S}=\frac{1}{I} \sum_{i=1}^{I} \frac{s_{i j}^{S}}{s_{i} *}$

If the value of $L O C_{j}^{S}$ is greater than zero, it indicates a high relative level of specialisation for region $j$.

Diversity (Jacobs' externalities)

Several index measurements can be applied to represent regional diversity. Following Duranton and Puga (2000), regional diversity in this study is measured by the inverse of the Hirschman-Herfindahl Index (HHI) of regional specialisation. This approach is the most popular in the empirical research. Following Nakamura and Paul (2009), the formula can be written as:

$D I V_{j}^{A}=1 / \sum_{i=1}^{I}\left(s_{i j}^{S}\right)^{2}$.

when the value of $D I V_{j}^{A}$ is equal to $I$ (the number of industries in the industrial classification), industrial employment in region $j$ is distributed among all industries.

Competition (Porter's externalities)

Following Nakamura and Paul (2009), the degree of competition in this study is measured by the ratio of the employment (labour)-based location quotient $\left(L Q_{i j}^{S(E)}\right)$ to the plant (firm)-based location quotient $\left(L Q_{i j}^{S(P)}\right)$. Therefore, if $L Q_{i j}^{S(E)}>L Q_{i j}^{S(P)}$, so that the ratio is greater than one, region $j$ contains relatively large plants and has a monopolistic/oligopolistic regional environment. However, if $L Q_{i j}^{S(P)}>L Q_{i j}^{S(E)}$, so that the ratio is less than one, region $j$ contains relatively small plants and has a competitive regional environment. The formula of $\left(L Q_{i j}^{S(E)}\right)$ and $\left(L Q_{i j}^{S(P)}\right)$ can be written as:

$L Q_{i j}^{S(E)}=\frac{S_{i j}^{S}}{S_{i^{*}}}=\frac{X_{i j} / X_{*_{j}}}{X_{i^{*}} / X_{* *}}, i=1, \ldots, I$

$L Q_{i j}^{S(P)}=\frac{S_{i j}^{S}}{S_{i^{*}}}=\frac{X_{i j} / X_{* j}}{X_{i *} / X_{* *}}, i=1, \ldots, I$

and competition or Porter's externalities is written as:

Competition $=L Q_{i j}^{S(E)} / L Q_{i j}^{S(P)}$ 


\section{References}

Andersoon, M., and H. Lööf. 2011. Agglomeration and productivity: Evidence from firmlevel data. Annal Regional Science 46: 601-620.

Batisse, C. 2002. Dynamic externalities and local growth: A panel data analysis applied to Chinese provinces. China Economic Review 13 (2/3): 231-251.

Beaudry, C., and A. Schiffauerova. 2009. Who's right, Marshall or Jacobs? The localization versus urbanization debate. Research Policy 38: 318-337.

Bhandari, A. K., and S. C. Ray. 2012. Technical efficiency in the Indian textiles industry: A non-parametric analysis of firm-level data. Bulletin of Economic Research 64 (1): $109-124$.

Cameron, A. C., and P. K. Trivedi. 2010. Microeconometrics Using Stata. Revised ed. College Station, Texas: Stata Press.

Cappelo, R. 2002. Spatial and sectoral characteristics of relational capital in innovation activity. European Planning Studies 10 (2): 177-200.

Cingano, F., and F. Schivardi. 2004. Identifying the sources of local productivity growth. Journal of the European Economic Association 2 (4): 720-742.

Cohen, J. P., and C. J. M. Paul. 2009. Agglomeration, productivity and regional growth: production theory approaches. In Handbook of Regional Growth and Development Theories, ed. R. Capello and P. Nijkamp, 101-117. Cheltenham, UK: Edward Elgar.

Combes, P.-P. 2000. Economic structure and local growth: France, 1984-1993. Journal of Urban Economics 47 (3): 329-355.

deGroot, H. L. F., J. Poot, and M. J. Smit. 2009. Agglomeration externalities, innovation and regional growth: Theoretical perspectives and meta-analysis. In Handbook of Regional Growth and Development Theories, ed. R. Capello and P. Nijkamp, 256281. Cheltenham, UK: Edward Elgar.

Discroll, J. C., and A. C. Kraay. 1998. Consistent covariance matrix estimation with spatially dependent panel data. Review of Economics and Statistics 80: 549-560.

Duranton, G., and D. Puga. 2000. Diversity and specialization in cities: Why, where and when does it matter? Urban Studies 37: 533-555.

2001. Nursery cities: Urban diversity, process innovation, and life-cycle of products. American Economic Review 91 (5): 1454-1477.

2004. Micro-foundations of urban agglomeration economies. In Handbook of Regional and Urban Economics, ed. J. V. Henderson and T. Jacques-Francois, 20632117. Amsterdam: Elsevier.

Ellison, G., and E. L. Glaeser. 1997. Geographic concentration in U.S. manufacturing industries: A dartboard approach. Journal of Political Economy 105 (5): 889-927.

Fan, C. C., and A. J. Scott. 2003. Industrial agglomeration and development: A survey of spatial economic issues in east asia and a statistical analysis of chinese regions. Economic Geography 79 (3): 295-319.

Felipe, J., and G. Estrada. 2007. Benchmarking developing Asia's manufacturing sector. ERD Working Paper Series no. 101, ADB: 1-39. http://www.adb.org/economics (accessed March 12, 2010).

Frenken, K., F. van Oort, and T. Verburg. 2005. Variety and regional economic growth in Netherlands. Working Paper-Utrecht University 05.02. http://econ.geo.uu.nl/peeg/peeg0502.pdf (accessed March 17, 2013).

Glaeser, E. L., H. D. Kallal, J. A. Scheinkman, and A. Shleifer. 1992. Growth in cities. Journal of Political Economy 100 (6): 1126-1152.

Graham, D. J., and H. Y. Kim. 2008. An empirical analytical framework for agglomeration economies. Annal Regional Science 42: 267-289.

Graham, D. J., P. S. Melo, P. Jiwattanakulpaisarn, and R. B. Nolan. 2010. Testing for causality between productivity and agglomeration economies. Journal of Regional Science 50 (5): 935-991. 
Greenstone, M., R. Hornbeck, and E. Moretti. 2008. Identifying agglomeration spillovers: Evidence from million dollar plants. http://www.nber.org/papers/w13833.

Gujarati, D. N., and D. C. Porter. 2009. Basic Econometrics. Fifth ed. New York: McGrawHill/Irwin.

Henderson, J. V. 2003. Marshall's scale economies. Journal of Urban Economics 53: 1-28.

Henderson, V., A. Kuncoro, and M. Turner. 1995. Industrial development in cities. Journal of Political Economy 103 (5): 1067-1090.

Henderson, J. V., T. Lee, and Y. J. Lee. 2001. Scale externalities in Korea. Journal of Urban Economics 49 (3): 479-504.

Hill, H. 1990. Indonesia's industrial transformation part II. Bulletin of Indonesian Economic Studies 26 (3): 75-109.

Hill, H., and K. P. Kalirajan. 1993. Small enterprise and firm-level technical efficiency in Indonesian garment industries. Applied Economics 25 (9): 1137-1144.

Hill, H., B. P. Resosudarmo, and Y. Vidyattama. 2008. Indonesia's changing economic geography. Bulletin of Indonesian Economic Studies 44 (3): 407-435.

Hoover, E. 1937. Location Theory and the Shoe and Leather Industries. Cambridge, Mass: Harvard University Press.

Ikhsan, M. 2007. Total factor productivity growth in Indonesian manufacturing: A stochastic frontier approach. Global Economic Review 36 (4): 321-342.

Jacob, J. 2005. Late industrialization and structural change: Indonesia, 1975-2000. Oxford Development Studies 33 (3/4): 427-451.

Jacobs, J. 1969. The Economy of Cities. New York: Vintage.

Kalkulis, S. 2010. Agglomeration economies and firm performance: The case of industry clusters. Journal of Management 36 (2): 453-481.

Katayama, H., S. Lu and J.R. Tybout. 2009, Firm-level productivity studies: Illusions and a solution. International Journal of Industrial Organisation 27: 403-413.

Krugman, P. 1991. Increasing returns and economic geography. Journal of Political Economy 99 (3): 483-499.

Kuncoro, A. 2009. Spatial agglomeration, firm productivity, and government policies in Indonesia: Concentration and deconcentration in the manufacturing sector. In Reshaping Economic Geography in East Asia, ed. Y. Huang and A. M. Bocchi, 156168. Washington, DC: The World Bank.

Lee, B. S., S. Jang, and S. H. Hong. 2010. Marshall's scale economies and Jacobs' externality in Korea: The role of age, size and the legal form of organisation of establishments. Urban Studies: 1-26.

Marshall, A. 1920. Principles of Economics. London: Macmillan.

Maskell, P., and L. Kebir. 2006. What qualifies as a cluster theory? In Clusters and Regional Development: Critical reflections and explorations, ed. B. Asheim, P. Cooke and R. Martin, 30-49. New York: Routledge.

Ministry of Industry Republic of Indonesia. 2009. Industrial development report 2004-2009. http://www.kemenperin.go.id/download/228/Laporan-Pengembangan-SektorIndustri-Tahun-2004-2009 (accessed July 3, 2012).

Nakamura, R., and C. J. M. Paul. 2009. Measuring agglomeration. In Handbook of Regional Growth and Development Theories, ed. R. Capello and P. Nijkamp, 305-328. Cheltenham, UK: Edward Elgar.

O'Donnell, C. J. 2010. Measuring and decomposing agricultural productivity and profitability change. The Australian Journal of Agricultural and Resources Economics 54: 527-560.

-------. 2011. The sources of productivity change in the manufacturing sectors of the U.S. economy. CEPA Working Papers: No. WP07/2011, Brisbane: University of Queensland.

2011a. DPIN 3.0: A program for decomposing productivity index numbers. CEPA Working Papers: Brisbane: University of Queensland. 
2012. An Aggregate quantity framework for measuring and decomposing productivity change. Journal of Productivity Analysis 38: 255-272.

Ohlin, B. 1933. Interregional and International Trade. Cambridge, Mass: Harvard University Press.

Pitt, M. M., and L. F. Lee. 1981. The measurement and sources of technical inefficiency in the Indonesian weaving industry. Journal of Development Economics 9: 43-64.

Porter, M. E. 1990. The Competitive Advantage of Nations. New York: The Free Press.

Quigley, J. M. 1998. Urban diversity and economic growth. Journal of Economic Perspectives 12 (2): 127-138.

Rosenthal, S. S., and W. C. Strange. 2004. Evidence on the nature and sources of agglomeration economies. In Handbook of Regional and Urban Economics, ed. J. V. Henderson and T. Jacques-Francois, 2119-2171. Amsterdam: Elsevier.

Setiawan, M., G. Emvalomatis, and A. O. Lansink. 2012. The relationship between technical efficiency and industrial concentration: Evidence from the Indonesian food and beverages industry. Journal of Asian Economics 23 (4): 466-475.

Shepard, R. W. 1953. Cost and Production Function. Princeton: Princeton University Press.

Suyanto, R. A. Salim, and H. Bloch. 2009. Does foreign direct investment lead to productivity spillovers? Firm level evidence from Indonesia. World Development 37 (12): 1861-1876.

Teece, D. J. 1986. Profiting from technological innovation: Implication for integration, collaboration, licensing and public policy. Research Policy 15 (6): 286-305.

Vial, V. 2006. New estimates of total factor productivity growth in Indonesian manufacturing. Bulletin of Indonesian Economic Studies 42 (3): 357-369.

Wheeler, J. O., P. O. Muller, G. I. Thrall, and T. J. Fik. 1998. Economic Geography. 3 ed. New York: John Wiley \& Sons.

Winter, S. 1987. Knowledge and competence as strategic assets. In The Competitive Challenge: Strategies for Industrial Innovation and Renewal, ed. D. Teece, 159-184. Cambridge: Mass: Ballinger. 